Journal of

Molecular Microbiology

and Biotechnology
J Mol Microbiol Biotechnol 2010;18:129-140

DOI: $\underline{10.1159 / 000308512}$

\title{
In vitro Phosphorylation of Key Metabolic Enzymes from Bacillus subtilis: PrkC Phosphorylates Enzymes from Different Branches of Basic Metabolism
}

\author{
Nico Pietack ${ }^{a}$ Dörte Becher ${ }^{b}$ Sebastian R. Schmidl ${ }^{a, c}$ Milton H. Saier ${ }^{c}$ \\ Michael Hecker $^{\text {b Fabian M. Commichau }}{ }^{a}$ Jörg Stülke ${ }^{a}$ \\ ${ }^{a}$ Department of General Microbiology, Institute of Microbiology and Genetics, Georg August University, \\ Göttingen, and ${ }^{\mathrm{b}}$ Institut für Mikrobiologie und Molekularbiologie, Ernst Moritz Arndt University, \\ Greifswald, Germany; ' Department of Biology, University of California at San Diego, San Diego, Calif., USA
}

\section{Key Words}

Protein phosphorylation - Phosphotransferase system •

Glycolysis $\cdot$ Tricarboxylic acid cycle $\cdot$ Serine/threonine kinase

\begin{abstract}
Phosphorylation is an important mechanism of protein modification. In the Gram-positive soil bacterium Bacillus subtilis, about $5 \%$ of all proteins are subject to phosphorylation, and a significant portion of these proteins is phosphorylated on serine or threonine residues. We were interested in the regulation of the basic metabolism in B. subtilis. Many enzymes of the central metabolic pathways are phosphorylated in this organism. In an attempt to identify the responsible protein kinase(s), we identified four candidate kinases, among them the previously studied kinase PrkC. We observed that PrkC is indeed able to phosphorylate several metabolic enzymes in vitro. Determination of the phosphorylation sites revealed a remarkable preference of PrkC for threonine residues. Moreover, PrkC often used several phosphorylation sites in one protein. This feature of PrkC-dependent protein phosphorylation resembles the multiple phosphorylations often observed in eukaryotic proteins. The HPr
\end{abstract}

protein of the phosphotransferase system is one of the proteins phosphorylated by PrkC, and PrkC phosphorylates a site (Ser-12) that has recently been found to be phosphorylated in vivo. The agreement between in vivo and in vitro phosphorylation of HPr on Ser-12 suggests that our in vitro observations reflect the events that take place in the cell.

Copyright $\odot 2010$ S. Karger AG, Basel

\section{Introduction}

Adaptation to changing environmental conditions is essential for life. The Gram-positive soil bacterium $\mathrm{Ba}$ cillus subtilis is permanently exposed to changing conditions, such as nutrient limitations or various physical stresses. In principle, there are three different mechanisms by which bacteria can adapt their metabolism to the environment: (1) alterations of gene expression, (2) changing the stabilities of proteins, and (3) modulation of enzymatic activities. Regulation of gene expression is by far the most intensively studied regulatory mechanism. There is a huge collection of studies concerning the response of $B$. subtilis to environmental changes at the proteome and/or transcriptome levels [Moreno et al., 2001;

\section{KARGER}

Fax +41613061234 E-Mail karger@karger.ch www.karger.com

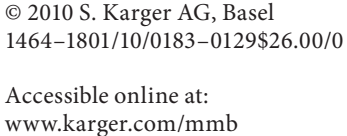

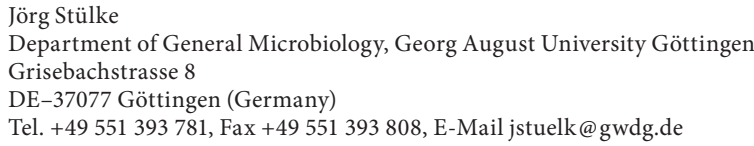


Eymann et al., 2002; Blencke et al., 2003]. In the past few years, when transcriptome and proteome studies became very popular, most regulatory effects were attributed to changes in transcription. However, changes in transcription are not always accompanied by corresponding changes in metabolic fluxes and vice versa [Schilling et al., 2007]. Thus, posttranslational regulatory mechanisms require our attention to fully understand regulatory phenomena.

In the past few years, it turned out that extensive protein phosphorylation not only on histidine but also on serine, threonine and tyrosine residues occurs in bacteria [Kennelly and Potts, 1996; Deutscher and Saier, 2005]. In B. subtilis, phosphorylation on histidine residues occurs in the phosphotransferase system (PTS) as well as in PTScontrolled transcription regulators and glycerol kinase. The sensor kinases of the two-component regulatory systems constitute a second class of His-phosphorylated proteins [Fabret et al., 1999; Reizer et al., 1999]. In the PTS, some phosphotransfer domains are phosphorylated on cysteine residues from which the phosphate is transferred to the incoming sugar. In contrast, the response regulators of the two-component systems are phosphorylated on aspartate residues by their cognate sensor kinases [Fabret et al., 1999; Reizer et al., 1999]. Phosphorylation on serine residues has long been studied for the HPr protein of the PTS that is phosphorylated on Ser- 46 by the metabolite-controlled HPr kinase/phosphorylase. HPr(SerP) then binds to the transcription factor CcpA and acts as a corepressor in carbon regulation [Görke and Stülke, 2008]. Regulatory phosphorylation of proteins on serine (and threonine) residues is also well established for the modulators of sigma factor activity in sporulation and stress response [Min et al., 1993; Yang et al., 1996]. Protein tyrosine phosphorylation is implicated in the control of the transcription repressor CtsR, of UDP-glucose dehydrogenases and of the single-stranded DNA-binding proteins [Grangeasse et al., 2007]. In total, about 200 proteins, representing $5 \%$ of all $B$. subtilis proteins, are now known to be phosphorylated [Lévine et al., 2006; Eymann et al., 2007; Macek et al., 2007].

With the large number of proteins phosphorylated on serine, threonine or tyrosine, the identification of the responsible kinase(s) is getting into the spotlight. So far, the HPr kinase and the three kinases involved in controlling sigma factor activities have been studied. All these kinases seem to phosphorylate clearly defined sites and are therefore not candidates for the phosphorylation of novel targets. In addition, the protein kinase PrkC can phosphorylate several proteins, including elongation factor $\mathrm{G}$ and PrkC itself [Gaidenko et al., 2002; Madec et al., 2002]. PrkC is a located in the cell membrane of vegetative cells and in the inner spore membrane of spores [Shah et al., 2008; Madec et al., 2002]. The prkC gene is part of the prpC-prkC-cpgA operon that is constitutively expressed throughout growth [Iwanicki et al., 2005]. Recently, stimulation of PrkC activity by muropeptides was reported. In spores, this activation of PrkC triggers germination, and prkC mutants are unable to germinate in response to muropeptides [Shah et al., 2008]. Homologues of PrkC are widespread in both Gram-positive and Gram-negative bacteria (fig. 1). This kinase is implicated in the phosphorylation of glycolytic enzymes and histone-like proteins as well as in pathogenicity in other Gram-positive bacteria [Jin and Pancholi, 2006; Kristich et al., 2007; Lomas-Lopez et al., 2007]. It is interesting to note that prkC is encoded in an operon with a corresponding protein phosphatase, PrpC [Madec et al., 2002]. This phosphatase is able to dephosphorylate $\mathrm{HPr}(\mathrm{Ser}-\mathrm{P})$ in B. subtilis and Mycoplasma pneumoniae [Halbedel et al., 2006; Singh et al., 2007].

We were interested in the regulation of carbon and nitrogen metabolism in B. subtilis. In an analysis of the transcriptome and metabolic flux responses to organic acids, we noticed that there are some cases where the changes in transcription do not match those in the metabolic fluxes. This is exemplified by the expression of the alsSD operon encoding acetolactate synthase and acetolactate decarboxylase and the corresponding acetoin production. Therefore, we considered posttranscriptional events to be important for metabolic adaptation [Schilling et al., 2007]. At the same time, phosphoproteome analyses demonstrated that indeed many enzymes of basic metabolism are subject to phosphorylation in B. subtilis [Lévine et al., 2006; Eymann et al., 2007; Macek et al., 2007]. Thus, protein phosphorylation might indeed play an important role for the adaptation of B. subtilis metabolism to changing conditions. However, the kinases responsible for these phosphorylation events have so far not been identified.

Fig. 1. Phylogenetic tree of PrkC homologues. The tree is based on a multiple alignment generated with the CLUSTAL X v2.0.12. program [Larkin et al., 2007]. The guide tree has been calculated using the UPGMA algorithm. The final phylogenetic tree was obtained using the Tree View X v 0.5.0 program (http://darwin. zoology.gla.ac.uk/ rpage/treeviewx/).
Pietack/Becher/Schmidl/Saier/Hecker/ Commichau/Stülke 


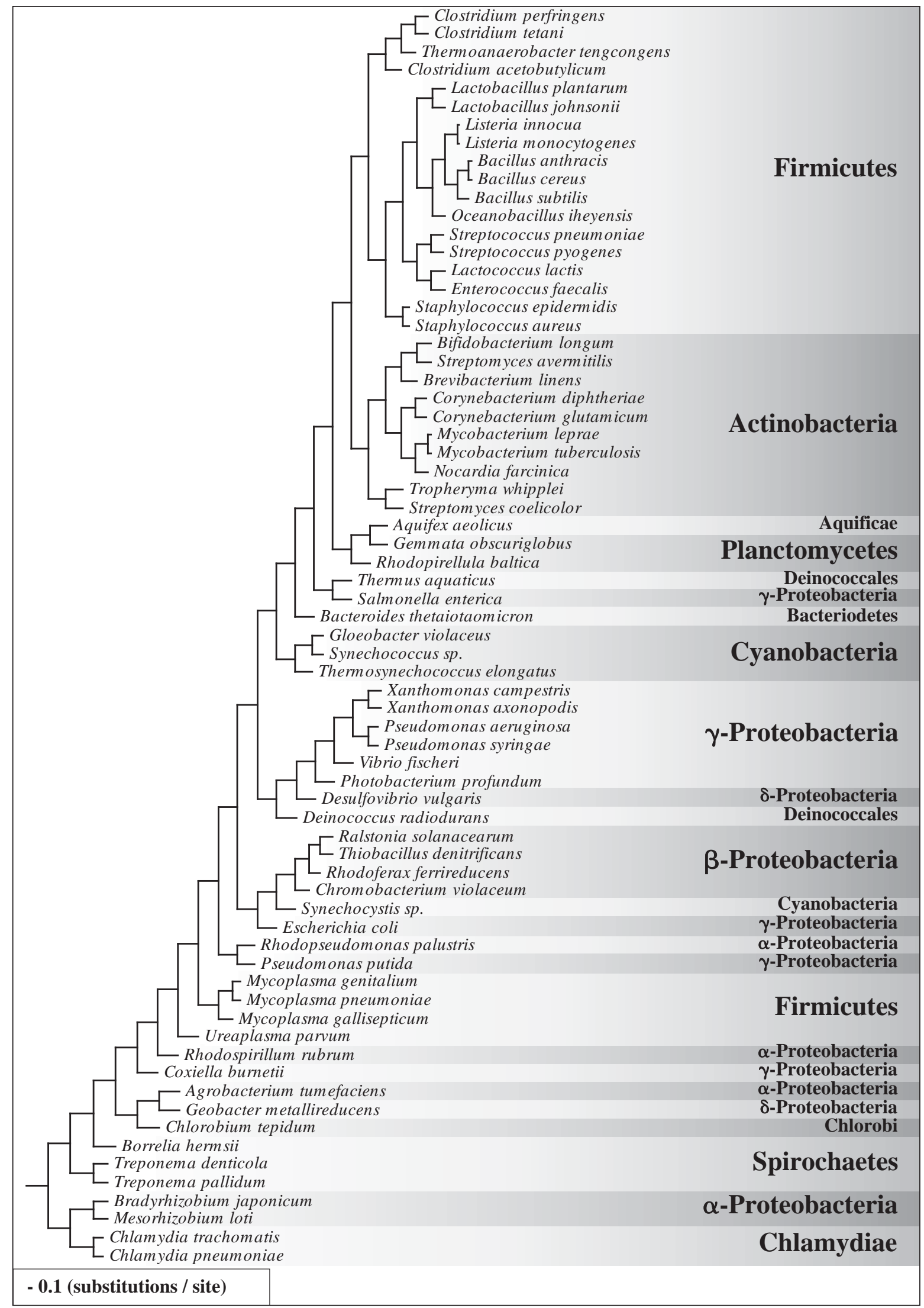


Table 1. Plasmids used in this work

\begin{tabular}{|c|c|c|c|c|c|c|}
\hline Plasmid & Gene & Protein & Affinity tag & Oligonucleotides & Vector & References \\
\hline pAG2 & ptsH & $\mathrm{HPr}$ & His-tag & & & Galinier et al. [1997] \\
\hline pGP174 & $g \ln A$ & glutamine synthetase & Strep-tag & & & Heinrich et al. [2006] \\
\hline pGP205 & $h p r K$ & HPr kinase & His-tag & & & Hanson et al. [2002] \\
\hline pGP371 & $p t s H^{*}$ & HPr-S46A & His-tag & SH82/SH83 & pWH844 & \\
\hline pGP563 & eno & enolase & His-tag & eno forw1/eno rev & pWH844 & \\
\hline pGP819 & $y w j H$ & transaldolase & Strep-tag & NP11/NP12 & pGP172 & \\
\hline pGP820 & $t k t$ & transketolase & Strep-tag & NP5/NP6 & pGP172 & \\
\hline pGP821 & $\operatorname{prkD}$ & protein kinase & Strep-tag & NP9/NP10 & pGP172 & \\
\hline pGP822 & alsD & $\alpha$-acetolactate decarboxylase & Strep-tag & NP1/NP2 & pGP172 & \\
\hline pGP823 & $y a b T$ & protein kinase & Strep-tag & NP7/NP8 & pGP172 & \\
\hline pGP824 & $y x a L$ & protein kinase & Strep-tag & NP13/NP14 & pGP172 & \\
\hline pGP825 & $\operatorname{prkC}$ & protein kinase & Strep-tag & NP3/NP4 & pGP172 & \\
\hline pGP931 & $i c d$ & isocitrate dehydrogenase & His-tag & FC17/FC18 & pWH844 & \\
\hline pGP1100 & pyk & pyruvate kinase & His-tag & pyk forw $1 /$ pyk rev & pWH844 & \\
\hline
\end{tabular}

* Indicates mutant alleles.

In this study, we intended to identify the kinase(s) for some of the enzymes of central metabolism by in vitro analysis of protein phosphorylation. Our work demonstrates that PrkC is able to phosphorylate several enzymes of different metabolic pathways. Moreover, PrkC was also responsible for a novel modification of the HPr protein of the PTS on Ser-12, an event previously observed in vivo [Macek et al., 2007]. Thus, PrkC may play an important role in phosphorylating proteins with different functions in B. subtilis.

\section{Results}

\section{Identification of Potential Serine/Threonine Protein}

Kinases in B. subtilis

The genome of $B$. subtilis encodes several proteins that are known or suspected to have serine/threonine kinase activity, among them the intensively studied HPr kinase/ phosphorylase and the kinases involved in the control of sigma factor activities. In addition, the PrkC serine/threonine kinase has been studied before. Analysis of the annotated genome sequence revealed the presence of three additional potential kinases: PrkD that is similar to the kinase domain of PrkC [Madec et al., 2002], YxaL and YabT.

\section{Purification of Selected Potential Protein Kinases and} Phosphorylation Targets

The four genes encoding the selected proteins were cloned into the expression vector pGP172, fusing them to an N-terminal Strep-tag. The proteins were expressed and purified using their affinity for Streptactin Sepharose. PrkC and PrkD were purified to apparent homogeneity. In contrast, we were unable to purify detectable amounts of YxaL. This may be due to the fact that YxaL is a secreted protein carrying a signal peptide [Tjalsma et al., 2004]. Similarly, only small amounts of YabT were obtained. Therefore, we concentrated our subsequent analyses on PrkC and PrkD.

Among the phosphoproteins that are involved in central metabolism, we selected glutamine synthetase $(\mathrm{Gln} \mathrm{A})$, enolase (Eno), transaldolase $(\mathrm{YwjH})$, transketolase (Tkt), $\alpha$-acetolactate decarboxylase (AlsD), isocitrate dehydrogenase (Icd), and pyruvate kinase (Pyk). These proteins were found to be phosphorylated in vivo on serine, threonine or tyrosine [Lévine et al., 2006; Eymann et al., 2007; Macek et al., 2007]. The corresponding genes were cloned into the expression vectors pWH844 and pGP172 to fuse the coding sequences to an N-terminal His- or Strep-tag, respectively (table 1). All these proteins were expressed in Escherichia coli and were purified to apparent homogeneity by affinity chromatography.

\section{Autophosphorylation of PrkC and PrkD}

First, we analyzed the autophosphorylation of the selected serine/threonine kinases, PrkC and PrkD. For this purpose, we incubated the two proteins in the presence of $\left[\gamma^{32} \mathrm{P}\right]$ ATP and analyzed them by SDS-PAGE. As shown in figure 2, both proteins exhibited autophosphorylation activity. This observation is in excellent agreement with 


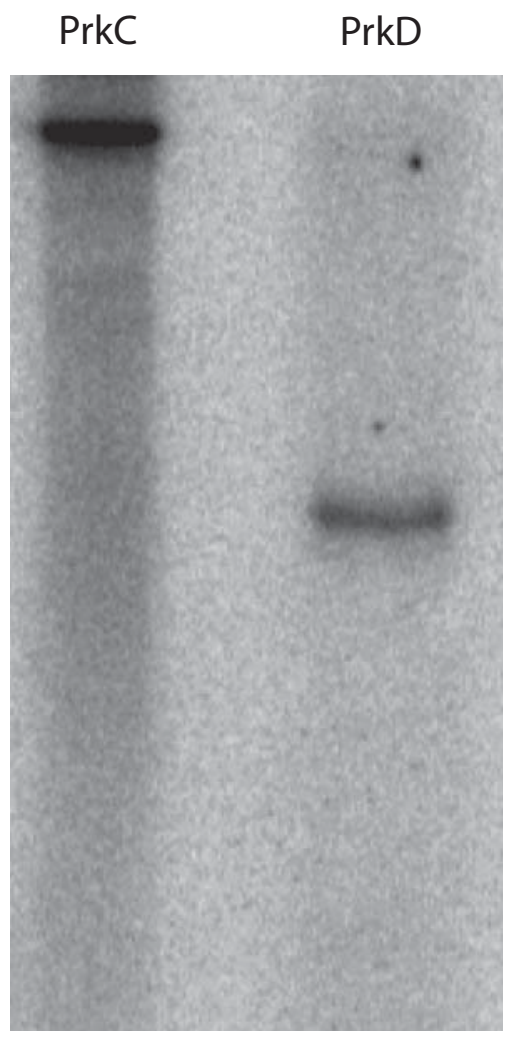

Fig. 2. Autophosphorylation of the serine/threonine kinases PrkC and PrkD. Two micrograms of each purified protein were incubated with $0.4 \mathrm{~mm}\left[\gamma-{ }^{32} \mathrm{P}\right] \mathrm{ATP}(480 \mathrm{Ci} / \mathrm{mmol})$ at $37^{\circ} \mathrm{C}$ for $30 \mathrm{~min}$ in assay buffer. The samples were then heated for $10 \mathrm{~min}$ at $95^{\circ} \mathrm{C}$ and loaded on a $16 \%$ SDS-PAGE gel. The gel was dried and analyzed by using a Storm 860 Molecular Imager, Molecular Dynamics.

a previous report on the autophosphorylation of PrkC [Madec et al., 2003]. To characterize these autophosphorylation events in more detail, we determined the phosphorylation sites by mass spectrometry using an LTQOrbitrap mass spectrometer. For PrkC, we detected six phosphorylation sites: Ser-214, Thr-290, Thr-313, Thr320 in the cytoplasmic kinase domain, and Thr-417 and Thr-498 in the extracytoplasmic domain. The phosphorylation sites in the kinase domain were also detected in a previous study that was exclusively devoted to the analysis of this domain [Madec et al., 2003]. Moreover, phosphorylation of Thr-290 was found to take place in vivo [Macek et al., 2007]. For PrkD, we found one phosphorylation site, Thr-174. It is interesting to note that the region surrounding this site is not conserved in PrkC. Similarly, the regions encompassing the phosphorylation sites in PrkC are not conserved in PrkD. Thus, both PrkD and

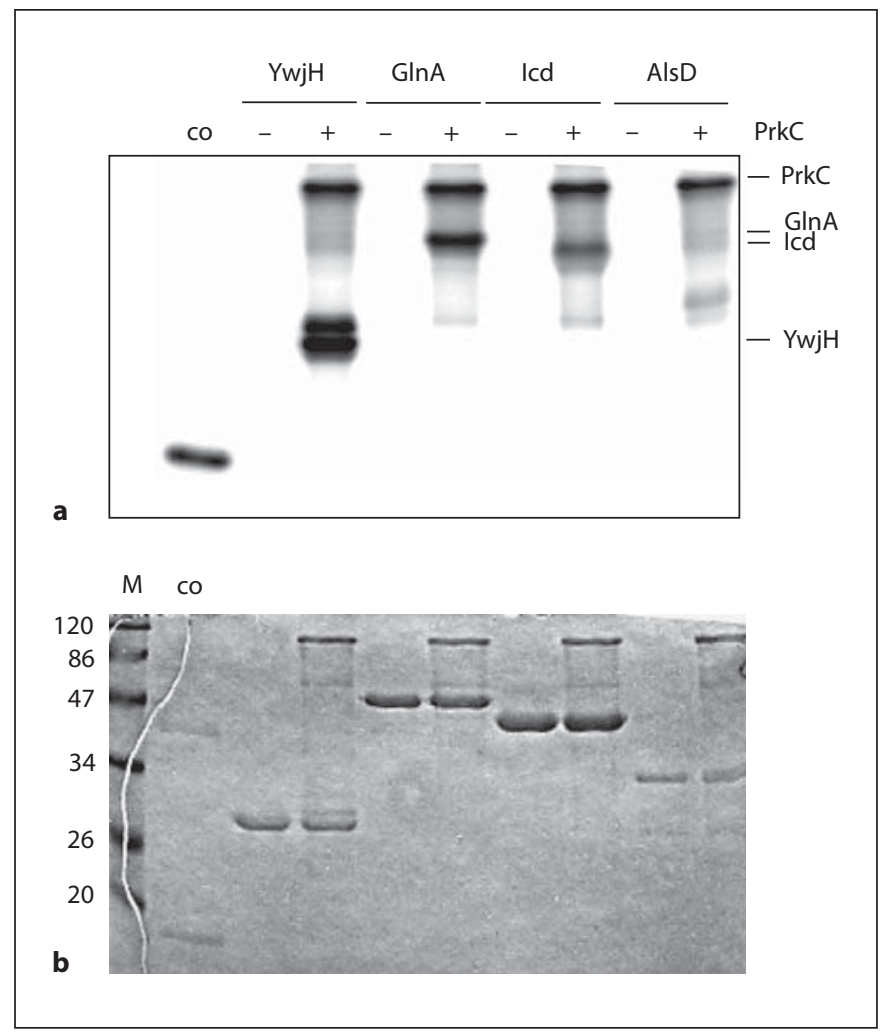

Fig. 3. Phosphorylation of potential target proteins by PrkC. Ten micrograms of the purified enzymes $\mathrm{YwjH}, \mathrm{Gln} \mathrm{A}$, Icd and AlsD were incubated with $0.4 \mathrm{~mm}\left[\gamma^{-32} \mathrm{P}\right] \mathrm{ATP}(480 \mathrm{Ci} / \mathrm{mmol})$ in the absence and in the presence of $2 \mu \mathrm{g} \operatorname{PrkC}$ at $37^{\circ} \mathrm{C}$ for $30 \mathrm{~min}$ in assay buffer. The samples were heated for $10 \mathrm{~min}$ at $95^{\circ} \mathrm{C}$ and loaded on a $16 \%$ SDS-PAGE gel. To obtain the autoradiogram, the gel was dried and analyzed using a Storm 860 Molecular Imager, Molecular Dynamics (a). In addition, the proteins were visualized by Coomassie-staining (b). co = Control (HPr phosphorylated by HPrK).

PrkC are mainly autophosphorylated on threonine residues, but the actual phosphorylation sites are not conserved even though 26 and $41 \%$ of identical and similar residues are conserved, respectively, for the $\mathrm{N}$-terminal 200 amino acids of the two kinases.

\section{Phosphorylation of the Potential Target Proteins}

The principal aim of this study was the investigation of phosphorylation of central metabolic enzymes of $B$. subtilis. To address this question, we incubated the putative kinase substrates with $\left[\gamma_{-}{ }^{32} \mathrm{P}\right] \mathrm{ATP}$ and either of the two kinases. Of the seven selected proteins, four were phosphorylated by PrkC (fig. 3). These were the transaldolase $\mathrm{YwjH}$, the glutamine synthetase $\mathrm{Gln} \mathrm{A}$, the isocitrate dehydrogenase Icd, and the $\alpha$-acetolactate decar- 
boxylase AlsD. In contrast, enolase, transketolase, and the pyruvate kinase PykA were not substrates for PrkCdependent phosphorylation (data not shown). However, the phosphorylation efficiency differed for the PrkC substrates: the phosphorylation efficiency of $\mathrm{YwjH}, \mathrm{G} \ln \mathrm{A}$ and Icd by PrkC was similar to that observed for HPrKdependent phosphorylation of $\mathrm{HPr}$ (fig. 3). In contrast, only weak signals were observed with AlsD (fig. 3). This might be caused by differences in the number of phosphorylation sites or in different affinities of PrkC for its respective substrates. The kinase assays with PrkD revealed that only Icd and GlnA were phosphorylated by PrkD (data not shown). However, these phosphorylation signals were extremely faint, which questions their biological relevance. Thus, our analysis revealed selective phosphorylation of four enzymes of central metabolism by PrkC.

\section{Determination of Phosphorylation Sites in the Target}

\section{Proteins}

In order to get new insights into PrkC substrates, we determined the phosphorylation sites of the proteins phosphorylated by PrkC. As observed for the autophosphorylation of PrkC, multiple phosphorylations with threonine as the major phosphoacceptor were observed. For the transaldolase $\mathrm{YwjH}$, we observed six sites that were phosphorylated by PrkC. The phosphorylated amino acids were scattered throughout the protein. There was one phosphorylated serine residue, Ser-55, and five phosphothreonines, i.e. Thr-26, Thr-82, Thr-125, Thr159, and Thr-184. Similar results were obtained with glutamine synthetase. This enzyme was phosphorylated on one serine resudue, Ser-207, and three threonine residues, Thr-26, Thr-147, and Thr-286. It is interesting to note that Thr-26 is located in the N-terminal $\beta$-grasp domain of the enzyme that is thought to be involved in binding of small molecules [Burroughs et al., 2007], whereas the other phosphorylation events take place in the catalytic domain of glutamine synthetase. Isocitrate dehydrogenase is phosphorylated by $\mathrm{PrkC}$ on three threonine residues, Thr-138, Thr-147 and Thr-396. In contrast to the other PrkC substrates (including PrkC autophosphorylation), the $\alpha$-acetolactate decarboxylase AlsD was phosphorylated by PrkC on a single serine residue, Ser- 88 .

\section{Phosphorylation of HPr by PrkC}

A recent analysis of the $B$. subtilis phosphoproteome revealed a novel phosphorylation of the HPr protein of the PTS on Ser-12 [Macek et al., 2007]. However, the source of this phosphorylation is not known so far. We

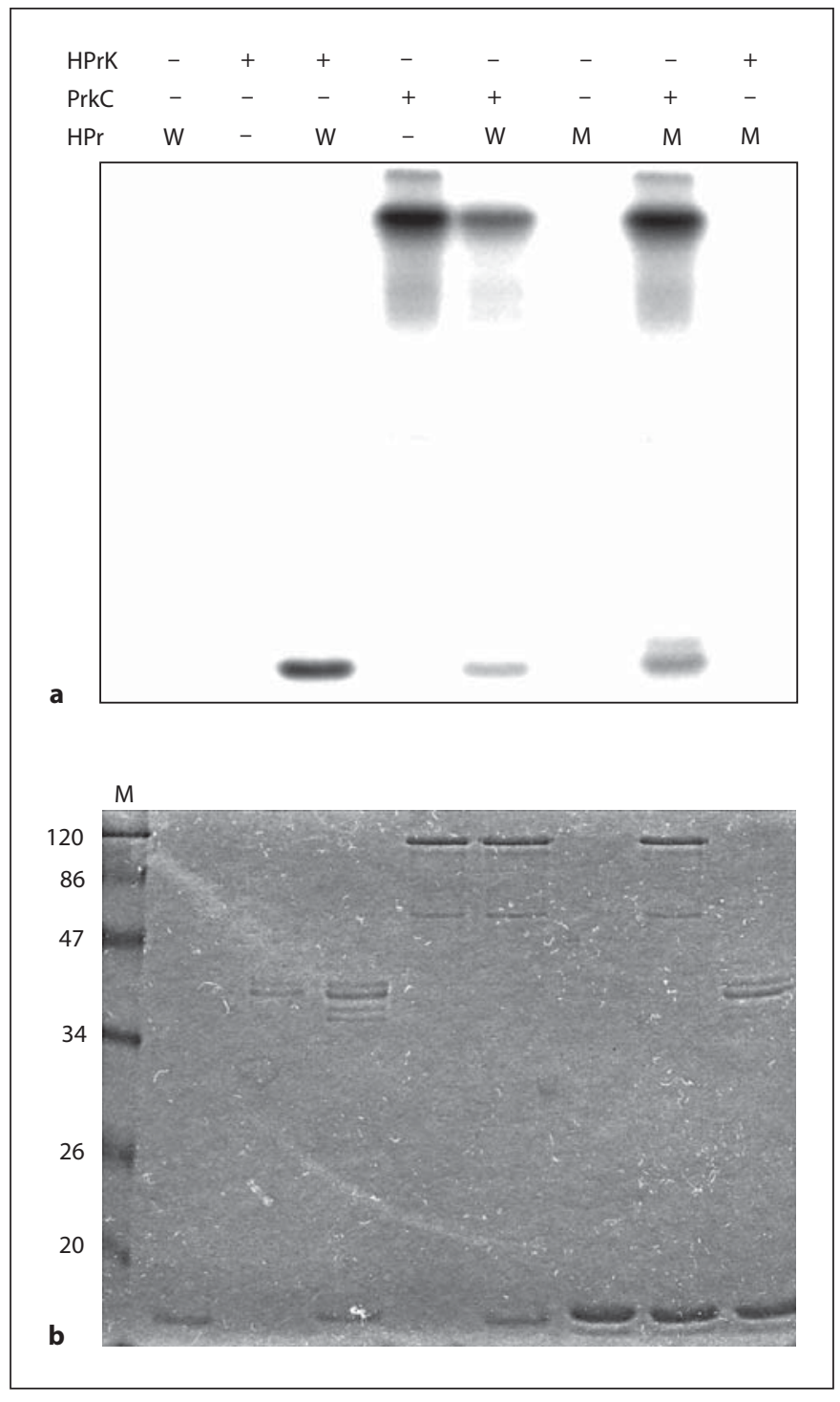

Fig. 4. Phosphorylation of wild-type HPr and HPr-S46A by PrkC and HPrK. Ten micrograms of the purified wild-type HPr (W) and $\mathrm{HPr}-\mathrm{S} 46 \mathrm{~A}(\mathrm{M})$ were incubated with $0.4 \mathrm{mM}\left[\gamma^{32} \mathrm{P}\right] \mathrm{ATP}(480$ $\mathrm{Ci} / \mathrm{mmol}$ ) in the absence and in the presence of either $2 \mu \mathrm{g}$ PrkC or $\mathrm{HPrK}$ at $37^{\circ} \mathrm{C}$ for $30 \mathrm{~min}$ in assay buffer. The samples were heated for $10 \mathrm{~min}$ at $95^{\circ} \mathrm{C}$ and loaded on a $16 \%$ SDS-PAGE gel. The autoradiogram (a) and the Coomassie-stained gel (b) were prepared as described in figure 2 .

considered the possibility that this phosphorylation might be caused by PrkC. Therefore, we assayed the phosphorylation of HPr in the presence of PrkC and $[\gamma$ $\left.{ }^{32} \mathrm{P}\right] \mathrm{ATP}$. The HPr kinase that phosphorylates HPr on Ser-46 served as a control. As shown in figure $4, \mathrm{HPr}$ was efficiently phosphorylated by the HPr kinase. Similarly, 


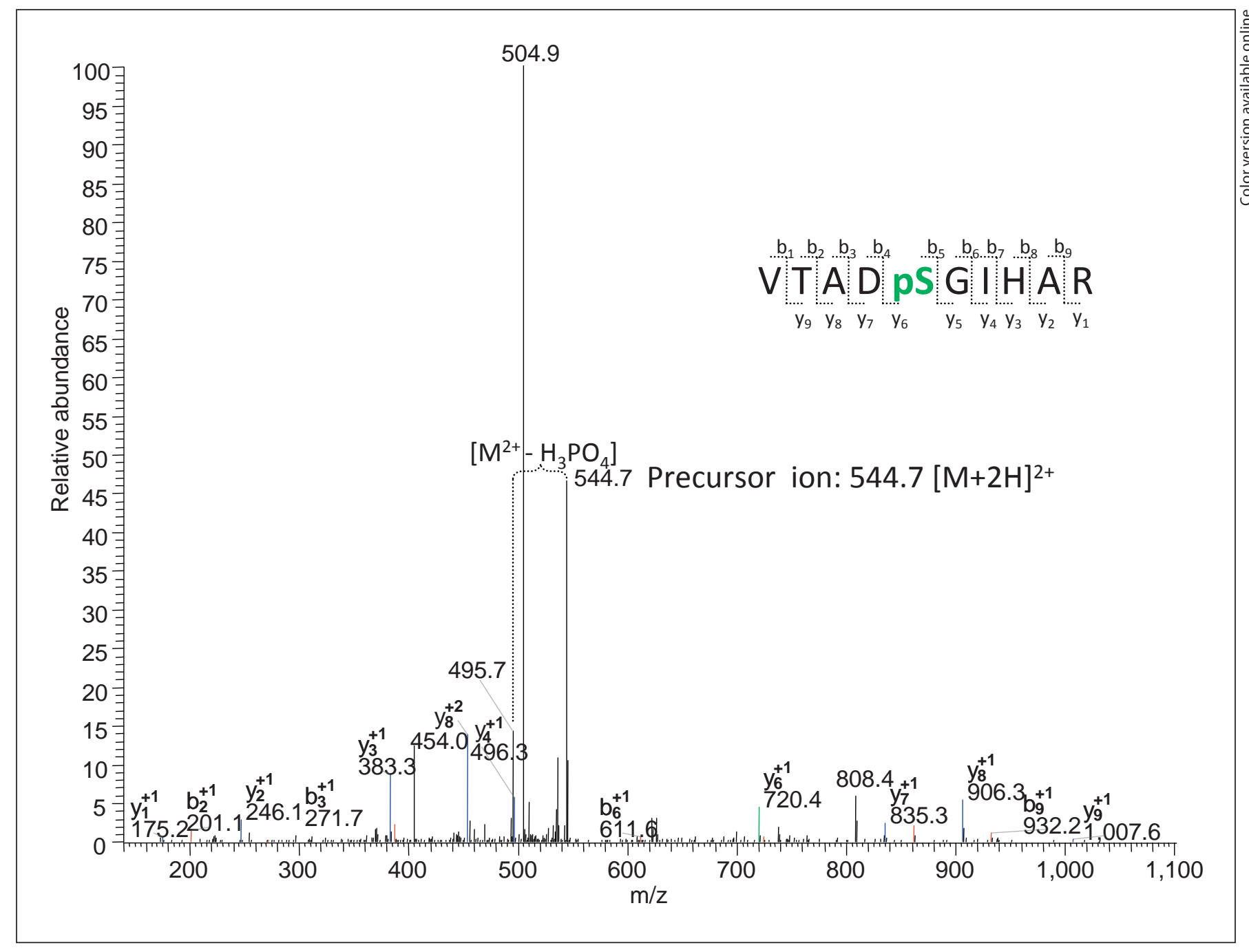

Fig. 5. Identification of the site of PrkC-dependent phosphorylation in HPr. The fragment ion spectrum of the HPr T2 peptide (VTADSGIHAR) with a precursor ion mass $544.7[\mathrm{M}+2 \mathrm{H}]^{2+}$ indicates a phosphate residue. The corresponding $\mathrm{b}$ - and $\mathrm{y}$-ions and the formation of the ion corresponding to the neutral loss of phosphoric acid from the doubly-charged precursor ion are highlighted and demonstrate the Ser-12 phosphorylation of $\mathrm{HPr}$.
PrkC was capable of phosphorylating HPr. Both HPrK (with its phosphorylase activity) and $\operatorname{PrpC}$, a protein phosphatase encoded in an operon with PrkC, are able to dephosphorylate $\mathrm{HPr}(\mathrm{Ser}-\mathrm{P})$ [Mijakovic et al., 2002; Singh et al., 2007]. Therefore, we considered the possibility that Ser-46 of HPr was the phosphorylation site used by HPrK as well as by PrkC. To address this problem, we used a mutant variant of the HPr protein devoid of its HPrK-dependent phosphorylation site (HPr-S46A) and tested the phosphorylation of this protein by the two kinases. As expected, the mutant protein was no longer phosphorylated by HPr kinase, thus confirming the conclusion that Ser-46 is the only phosphorylation site in HPr used by HPr kinase. In contrast, the mutant protein was still phosphorylated by PrkC, and the intensity of the phosphorylation signal was similar to that observed with the wild-type protein. These observations suggest that a site (or sites) distinct from Ser- 46 are the primary target(s) of PrkC-dependent phosphorylation in HPr.

The use of a different phosphorylation site by PrkC may suggest that Ser-12, a site phosphorylated in vivo [Macek et al., 2007], is the target of PrkC. This was verified by mass-spectrometric determination of the PrkC- 
dependent phosphorylation site (fig. 5). Indeed, the only phosphorylated site detected in this study was Ser-12. Thus, the in vitro activity of PrkC on HPr reflects the in vivo situation. This observation suggests that $\mathrm{PrkC}$ is the kinase that phosphorylates HPr in vivo on Ser-12.

\section{Discussion}

Protein phosphorylation is a very common event in all organisms [Ficarro et al., 2002; Levine et al., 2006; Eymann et al., 2007; Macek et al., 2007; Macek et al., 2008]. As much as about $5 \%$ of all proteins can be phosphorylated in organisms so different as the sporulating bacterium B. subtilis and the genome minimalist Mycoplasma genitalium [Su et al., 2007]. Two major questions remain to be answered: (1) which kinases are responsible for these phosphorylation events, and (2) what is the effect of the phosphorylation on the activity of the target proteins?

In this work, we addressed the first of these questions. In B. subtilis, only five serine/threonine kinases have been studied so far. These are HPr kinase, RsbT kinase, RsbW kinase and SpoIIAB kinase, involved in the control of sigma factor activities and PrkC [Min et al., 1993; Reizer et al., 1998; Madec et al., 2002]. In this work, we focussed on PrkC and its relative, PrkD. Indeed, our in vitro experiments revealed that $\operatorname{PrkC}$ is able to phosphorylate several of the proteins that were found to exist as phosphoproteins in vivo.

PrkC is implicated in sporulation, biofilm formation and germination [Gaidenko et al., 2002; Madec et al., 2002; Shah et al., 2008], but only two substrates (EF-G and PrkC itself) have been identified. Our work confirms that PrkC might be of global importance as it phosphorylates enzymes from different pathways, such as transaldolase, glutamine synthetase, isocitrate dehydrogenase, $\alpha$-acetolactate decarboxylase and HPr. However, among the eight phosphoproteins tested for phosphorylation by PrkC, three were not targets of this kinase. A global role for PrkC is supported by studies with other bacteria. In Staphylococcus aureus, PrkC phosphorylates glycolytic enzymes [Lomas-Lopez et al., 2007], whereas the $\alpha$-subunit of RNA polymerase and the phosphoglucosamine mutase are substrates of the Streptococcus pneumoniae PrkC homolog, StkP [Novákováa et al., 2005]. Moreover, PrkC homologs are important for virulence development and global gene expression in S. pneumoniae, S. aureus, M. pneumoniae and Bacillus anthracis [Sasková et al., 2007; Débarbouillé et al., 2009; Schmidl et al., 2010; Shakir et al., 2010]. Thus, PrkC can phosphorylate a wide range of proteins involved in a variety of cellular functions.

Another remarkable feature of PrkC is its obvious preference for threonine. This study presents a significant increase of the known phosphorylation sites used by PrkC. Of the sites identified here, 16 are threonines and only 5 are serine residues. In a previous study on PrkC autophosphorylation, 7 phosphorylated threonine residues and 1 serine residue were reported [Madec et al., 2003]. Our results confirm the autophosphorylation of Ser-214 as well as of Thr-290, Thr-313 and Thr-320. We failed to detect the phosphorylation of a stretch of multiple threonine residues in the $\mathrm{N}$-terminal part of PrkC, but instead we detected two phosphorylation sites in the extracellular domain of PrkC that was not included in the previous study [Madec et al., 2003]. In vivo phosphorylation of PrkC was observed on Thr-290 [Macek et al., 2007], thus providing a confirmation for our in vitro study. Studies on protein phosphorylation by PrkC proteins from Streptococcus pyogenes also revealed the use of threonine as the preferred phosphorylation target by PrkC [Jin and Pancholi, 2006]. The kinase domains of PrkC and PrkD are very similar to each other (about 30\% identical residues). However, the sites of autophosphorylation were not conserved between the two proteins although the only phosphorylation site identified for PrkD was also a threonine. A comparison of the regions around the PrkC-dependent phosphorylation sites revealed little conservation of the primary sequences, suggesting that it is not the primary sequence context that serves for recognition by PrkC.

An interesting aspect of this work is the identification of HPr as a novel target for PrkC. HPr is a paradigm of protein phosphorylation with its His- 15 and Ser- 46 phosphorylated by enzyme I of the PTS and by the ATP-dependent HPr kinase, respectively [Reizer et al., 1998]. Analysis of the B. subtilis phosphoproteome revealed the phosphorylation of yet another site, Ser-12. We could attribute this phosphorylation event to the activity of PrkC. This finding suggests that our in vitro observations regarding PrkC-dependent protein phosphorylation reflect the in vivo activity of PrkC and the physiological interactions with the different target proteins. However, it is not known whether this phosphorylation affects the biological activity of HPr. The weak phosphorylation of Ser-12 by PrkC suggests that this phosphorylation does not affect the properties of the cellular HPr. Similar results have been obtained for the transcription antiterminator GlcT, which can be phosphorylated and inactivated to a minor degree by HPr under conditions in which its full activity 
Table 2. Oligonucleotides used in this study

\begin{tabular}{|c|c|}
\hline Oligonucleotide & Sequence $\left(5^{\prime} \rightarrow 3^{\prime}\right)$ \\
\hline CD13 & AAACATATGGCTAGCTGGAGCCACCCGCAGTTC \\
\hline eno forw1 & AAGGATCCCCATACATTGTTGATGTTTATGCAC \\
\hline eno rev & TTTCTGCAGTTACTTGTTTAAGTTGT AGAAAGAGTTG \\
\hline FC17 & AAAGGATCCGTGGCACAAGGTGAAAAAATTAC \\
\hline FC18 & TTTETGCAGTTATTAGTCCATGTTTTTGAT \\
\hline JS39 & TCTATCAACAGGAGTCCAAGC \\
\hline NP1 & AAAGAGCTCCGATGAAACGAGAAAGCAACATTC \\
\hline NP2 & TTTGGATCCCTATTATTCAGGGCTTCCTTCAGT \\
\hline NP3 & AAAGAGCTCCGGTGCTAATCGGCAAGC \\
\hline NP4 & TTTAGATCTTCATTATTCATCTTTCGGATACTCAAT \\
\hline NP5 & AAAGAGCTCGATGGATACAATTGAAAAGAAATCAG \\
\hline NP6 & TTTGGATCCTCATTACTTATTGATTAATGCCTTAAC \\
\hline NP7 & AAAGAGCTCGATGATGAACGACGCTTTGAC \\
\hline NP8 & 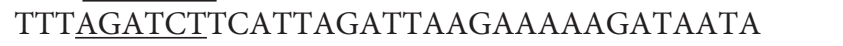 \\
\hline NP9 & AAAGAGCTCGATGGCATTAAAACTTCTAAAAAA \\
\hline NP10 & TTTGGATCCTCATTATGTGACCGATTGAATGGC \\
\hline NP11 & AAAGAGCTCGATGTTATTCTTTGTTGATACAG \\
\hline NP12 & TTTGGATCCTCATTATTTGTTCCAGTCTGCC \\
\hline NP13 & AAAGAGCTCGATGGTCAAGTCATTTCG \\
\hline NP14 & TTTGGATCCTCATTATTTCCCAAAAGCCATCAG \\
\hline NP15 & CCGGTGTTCACGGTGCGCCGCTTGG \\
\hline NP16 & CTCACCTGATTCTTTAACAGCTACAGCG \\
\hline NP17 & CTTGCTAAAGCTGCTGGCGAAAAGAAGCTG \\
\hline NP18 & ATCGTGAGCAAAACCCACGGCCAC \\
\hline NP19 & ATGTTCACGCGATCAAACCGACGTC \\
\hline NP20 & GCAGCAGCCAACTCAGCTTCCTTTCGGGC \\
\hline pWH844 fw & TATGAGAGGATCGCATCACCAT \\
\hline pyk forw1 & AAGGATCCAGAAAAACTAAAATTG TTTGTACCATCGG \\
\hline pyk rev & TTTCTGCAGTTAAAGAACGCTCGCA CGG \\
\hline SH82 & ATGGATCCATGGCACAAAAAACATTTAAAG \\
\hline SH83 & ATAAAGCTTCTCGCCGAGTCCTTCG \\
\hline
\end{tabular}

is required. Again, this phosphorylation affects only a small fraction of the cellular GlcT pool and, therefore, does not influence GlcT-mediated regulation [Schmalisch et al., 2003].

Our work suggests that PrkC is a protein kinase which may have global importance in B. subtilis. However, important questions remain to be answered: which other proteins does PrkC phosphorylate? Phosphoproteome studies with prkC mutants might be helpful to address this question. Does PrkC-dependent phosphorylation serve for fine-tuning of the metabolism, does it tag the proteins for degradation, or does it serve completely different purposes? Finding the answers to these questions is challenging, but these answers will have a significant impact on our understanding of microbial physiology.

Protein Phosphorylation in Bacillus subtilis

\section{Experimental Procedures}

Bacterial Strains, Oligonucleotides and Growth Conditions

B. subtilis 168 (wild type, laboratory collection) and QB5223 (ptsH1) [Martin-Verstraete et al., 1995] were used to isolate chromosomal DNA for the amplification of the desired genes. E. coli DH5 $\alpha$ and BL21 (DE3)/pLysS [Sambrook et al., 1989] were used for cloning experiments and protein expression, respectively. $B$. subtilis was grown in TY medium $(1 \% \mathrm{w} / \mathrm{v}$ tryptone, $0.5 \% \mathrm{w} / \mathrm{v}$ yeast extract, and $1 \% \mathrm{w} / \mathrm{v} \mathrm{NaCl})$. E. coli was grown in Luria-Bertani medium (LB medium), and transformants were selected on plates containing ampicillin $(100 \mu \mathrm{g} / \mathrm{ml})$. LB plates were prepared by the addition of $17 \mathrm{~g}$ Bacto agar (Difco) per liter of LB medium. The oligonucleotides used in this study are listed in table 2 .

DNA Manipulation

Transformation of E. coli and plasmid DNA extraction were performed using standard procedures [Sambrook et al., 1989]. Restriction enzymes, T4 DNA ligase and DNA polymerases were used as recommended by the manufacturers. DNA fragments

J Mol Microbiol Biotechnol 2010;18:129-140 
were purified from agarose gels using the QIAquick PCR Purification kit (Qiagen, Germany). Pfu DNA polymerase was used for the polymerase chain reaction as recommended by the manufacturer. DNA sequences were determined using the dideoxy chain termination method [Sambrook et al., 1989]. All plasmid inserts derived from PCR products were verified by DNA sequencing. Chromosomal DNA of $B$. subtilis was isolated as described [Martin-Verstraete et al., 1995].

\section{Plasmid Constructions}

The plasmids used for the expression of tagged B. subtilis proteins in $E$. coli were constructed using the expression vectors pWH844 [Schirmer et al., 1997] or pGP172 [Merzbacher et al., 2004] that allow the fusion of the cloned proteins to an N-terminal His- or Strep-tag, respectively. These plasmids are listed in table 1 .

For the expression of the S46A mutant variant of the HPr proteins, plasmid pGP371 was constructed by cloning of the ptsH1 DNA fragment from B. subtilis QB5223 (table 1). B. subtilis $\mathrm{HPr}$ kinase and wild-type HPr were expressed using pGP205 and pAG2, respectively [Galinier et al., 1997; Hanson et al., 2002].

\section{Overexpression and Purification of Recombinant Proteins}

E. coli BL21(DE3)/pLysS was used as host for the overexpression of recombinant proteins. Expression was induced by the addition of IPTG (final concentration $1 \mathrm{mM}$ ) to exponentially growing cultures $\left(\mathrm{OD}_{600}\right.$ of 0.8$)$. Cells were lysed using a French press (20,000 p.s.i., $138,000 \mathrm{kPa}$; Spectronic Instruments, UK). After lysis, the crude extracts were centrifuged at $15,000 \mathrm{~g}$ for $1 \mathrm{~h}$. For purification of His-tagged proteins, the resulting supernatants were passed over an $\mathrm{Ni}^{2+}$ HiTrap chelating column (5 $\mathrm{ml}$ bed volume, Pharmacia) followed by elution with an imidazole gradient (from 0 to $500 \mathrm{mM}$ imidazole in a buffer containing $10 \mathrm{mM}$ Tris$\mathrm{HCl} \mathrm{pH} \mathrm{7.5,} 600 \mathrm{~mm} \mathrm{NaCl}, 10 \mathrm{~mm} \beta$-mercaptoethanol) over $30 \mathrm{ml}$ at a flow rate of $0.5 \mathrm{ml} / \mathrm{min}$. For proteins carrying an $\mathrm{N}$-terminal Strep-tag, the crude extract was passed over a Streptactin column (IBA, Göttingen, Germany). The recombinant protein was eluted with desthiobiotin (Sigma, final concentration $2.5 \mathrm{mM}$ ).

After elution, the fractions were tested for the desired protein using $12.5 \%$ SDS-PAGE gels. The relevant fractions were combined and dialyzed overnight. Protein concentration was determined using the Bio-Rad dye-binding assay with bovine serum albumin serving as the standard.

\section{Assays for Protein Phosphorylation}

Activity assays of potential protein kinases were carried out with purified proteins in assay buffer $\left(10 \mathrm{mM} \mathrm{MgCl}_{2}, 25 \mathrm{mM}\right.$ Tris$\mathrm{HCl} \mathrm{pH} \mathrm{7.6,} 1 \mathrm{~mm}$ dithiothreitol, $0.4 \mathrm{~mm}\left[\gamma^{32} \mathrm{P}\right] \mathrm{ATP}(480 \mathrm{Ci} /$ mmol)) using purified target proteins. For assays of HPr kinase activity, fructose 1,6-bisphosphate was added to a final concentration of $25 \mathrm{~mm}$. The assays were carried out at $37^{\circ} \mathrm{C}$ for $30 \mathrm{~min}$ followed by thermal inactivation of the enzyme $\left(10 \mathrm{~min}\right.$ at $\left.95^{\circ} \mathrm{C}\right)$. The assay mixtures were analyzed on $16 \%$ SDS-polyacrylamide gels. Proteins were visualized by Coomassie staining.

\section{Protein Identification by Mass Spectrometry}

Peptide preparation was carried out as recently described [Eymann et al., 2007]. Excised polyacrylamide gel pieces of stained protein bands were washed with $100 \mu \mathrm{l}$ of $200 \mathrm{mM} \mathrm{NH}_{4} \mathrm{HCO}_{3}$ in $50 \% \mathrm{CH}_{3} \mathrm{CN}$ for $20 \mathrm{~min}$ at $37^{\circ} \mathrm{C}$ and dried in a vacuum centrifuge for $20 \mathrm{~min}$. In-gel digestion with trypsin (Promega, Madison, Wisc., USA) was performed overnight at $37^{\circ} \mathrm{C}$. After addition of $15 \mu \mathrm{l}$ formic acid $(5 \%, \mathrm{v} / \mathrm{v})$, samples were incubated in an ultrasonic bath for $20 \mathrm{~min}$. The supernatant was transferred into microsample vials and stored for LC-MS/MS analysis at $4^{\circ} \mathrm{C}$.

LC-MS/MS analysis was performed using either an LTQ-Orbitrap mass spectrometer (Thermo Electron, San Jose, Calif., USA) in conjunction with a nanoACQUITY UPLC ${ }^{\text {TM }}$ system (Waters, Milford, Mass., USA) or a Q-Star Pulsar mass spectrometer (Applied Biosystems MDS Sciex) in conjunction with the Ettan MDLC system (GE Healthcare, Munich, Germany).

In the nanoACQUITY UPLC system, peptides were loaded onto a trapping column (nanoAcquity UPLC Column, Symme$\operatorname{try}^{\circledR} \mathrm{C} 185 \mu \mathrm{m}, 180 \mu \mathrm{m} \times 20 \mathrm{~mm}$, Waters) and washed for $3 \mathrm{~min}$ with $99 \%$ buffer A ( $0.1 \% \mathrm{v} / \mathrm{v}$ formic acid) at a flow rate of $10 \mu \mathrm{l} /$ min and separated on an analytical column (BEH130 C18 $1.7 \mu \mathrm{m}$, $100 \mu \mathrm{m} \times 100 \mathrm{~mm}$, Waters) in a linear gradient from 99\% buffer A to $60 \%$ buffer B ( $90 \% \mathrm{v} / \mathrm{v}$ acetonitrile, $0.1 \% \mathrm{v} / \mathrm{v}$ acetic acid) in 80 $\mathrm{min}$. The flow rate during elution was set to $1 \mu \mathrm{l} / \mathrm{min}$. In the Et$\tan$ MDLC system, the peptides were loaded onto a trapping column $\left(\mu\right.$-Precolumn, PepMap ${ }^{\mathrm{TM}}, \mathrm{C} 18,300 \mu \mathrm{m}$ i.d. $\times 5 \mathrm{~mm}, \mathrm{LC}$ Packings), washed for 15 min with buffer $\mathrm{A}$ and separated onto the analytical column (PepMap, C18, $75 \mu \mathrm{m}$ i.d. $\times 15 \mathrm{~cm}, \mathrm{LC}$ Packings) by formation of a 70 -min gradient of $99 \%$ buffer buffer A to $60 \%$ buffer $\mathrm{B}$ at a flow rate of $200 \mathrm{nl} / \mathrm{min}$.

The LTQ-Orbitrap was employed to acquire a full Orbitrap survey scan in the range $\mathrm{m} / \mathrm{z}$ 300-2,000. Subsequently, MS/MS experiments of the three most abundant precursor ions were carried out in the LTQ. Meanwhile, the masses of the precursor ions were determined with high accuracy via single-ion mode scans in the Orbitrap cell of the mass spectrometer. The Qstar system was used to carry out a survey scan in the mass range of $\mathrm{m} / \mathrm{z} 230-2,000$ in the first step. In a second step, up to four precursor ions were selected for a fragmentation in MS/MS experiments. Product ions were detected in the range of $\mathrm{m} / \mathrm{z} 70-2,000$. The data were analyzed as described [Eymann et al., 2007].

\section{Acknowledgements}

Oliver Schilling, Sven Halbedel and Christina Herzberg are acknowledged for their help with some experiments. Finally, we wish to express our gratitude to Josef Deutscher and Boris Görke for their interest in this work and their valuable suggestions. This work was supported by grants of the Deutsche Forschungsgemeinschaft, the Fonds der Chemischen Industrie and the BMBF (SYSMO, PtJ-BIUO/0313978D) to J.S. 


\section{References}

Blencke HM, Homuth G, Ludwig H, Mäder U, Hecker M, Stülke J: Transcriptional profiling of gene expression in response to glucose in Bacillus subtilis: regulation of the central metabolic pathways. Metab Eng 2003;5:133149.

-Burroughs AM, Balaji S, Iyer LM, Aravind L: Small but versatile: the extraordinary functional and structural diversity of the betagrasp fold. Biol Direct 2007;2:18.

-Débarbouillé M, Dramsi S, Dussurget O, Nahori MA, Vaganay E, Jouvion G, Cozzone A, Msadek T, Duclos B: Characterization of a serine/threonine kinase involved in virulence of Staphylococcus aureus. J Bacteriol 2009;191:4070-4081.

- Deutscher J, Saier MH Jr: Ser/Thr/Tyr phosphorylation in bacteria - for long time neglected, now well established. J Mol Microbiol Biotechnol 2005;9:125-131.

-Eymann C, Becher D, Bernhardt J, Gronau K, Klutzny A, Hecker M: Dynamics of protein phosphorylation on Ser/Thr/Tyr in Bacillus subtilis. Proteomics 2007;7:3509-3526.

-Eymann C, Homuth G, Scharf C, Hecker M: Bacillus subtilis functional genomics: global characterization of the stringent response by proteome and transcriptome analysis. J Bacteriol 2002; 184:2500-2520.

-Fabret C, Feher VA, Hoch JA: Two-component signal transduction in Bacillus subtilis: how one organism sees its world. J Bacteriol 1999; 181:1975-1983.

- Ficarro SB, McClelland ML, Stukenberg PT, Burke DJ, Ross MM, Shabanowitz J, Hunt DF, White FM: Phosphoproteome analysis by mass spectrometry and its application to Saccharomyces cerevisiae. Nat Biotechnol 2002;20:301-305.

Gaidenko TA, Kim TJ, Price CW: The PrpC serine-threonine phosphatase and PrkC kinase have opposing physiological roles in stationary-phase Bacillus subtilis cells. J Bacteriol 2002;184:6109-6114.

-Galinier A, Haiech J, Kilhoffer MC, Jaquinod M, Stülke J, Deutscher J, Martin-Verstraete I: The Bacillus subtilis crh gene encodes a HPrlike protein involved in carbon catabolite repression. Proc Natl Acad Sci USA 1997;94: 8439-8444.

Görke B, Stülke J: Carbon catabolite repression in bacteria: many ways to make the most out of nutrients. Nat Rev Microbiol 2008;6:613624.

-Grangeasse C, Cozzone AJ, Deutscher J, Mijakovic I: Tyrosine phosphorylation: an emerging regulatory device of bacterial physiology. Trends Biochem Sci 2007;32:8694.

Halbedel S, Busse J, Schmidl S, Stülke J: Regulatory protein phosphorylation in Mycoplasma pneumoniae: a PP2C-type phosphatase serves to dephosphorylate $\mathrm{HPr}(\mathrm{Ser}-\mathrm{P})$. J Biol Chem 2006;281:26253-26259.
Hanson KG, Steinhauer K, Reizer J, Hillen W, Stülke J: HPr kinase/phosphatase of Bacillus subtilis: expression of the gene and effects of mutations on enzyme activity, growth, and carbon catabolite repression. Microbiology 2002;148:1805-1811.

Heinrich A, Woyda K, Brauburger K, Meiss G, Detsch C, Stülke J, Forchhammer K: Interaction of the membrane-bound GlnK-AmtB complex with the master regulator of nitrogen metabolism TnrA in Bacillus subtilis. J Biol Chem 2006;281:34909-34917.

Iwanicki A, Hinc K, Seror S, Węgrzyn G, Obuchowski M: Transcription in the prpC-yloQ region in Bacillus subtilis. Arch Microbiol 2005; 183:421-430.

Jin H, Pancholi V: Identification and biochemical characterization of a eukaryotic-type serine/threonine kinase and its cognate phosphatase in Streptococcus pyogenes: their biological functions and substrate identification. J Mol Biol 2006;357:1351-1372.

Kennelly PJ, Potts M: Fancy meeting you here! A fresh look at 'prokaryotic' protein phosphorylation. J Bacteriol 1996;178:4759-4764.

Kristich CJ, Wells CL, Dunny GM: A eukaryotictype Ser/Thr kinase in Enterococcus faecalis mediates antimicrobial resistance and intestinal persistence. Proc Natl Acad Sci USA 2007;104:3508-3513.

Larkin MA, Blackshields G, Brown NP, Chenna R, McGettigan PA, McWilliam H, Valentin F, Wallace IM, Wilm A, Lopez R, Thompson JD, Gibson TJ, Higgins DG: Clustal W and Clustal X version 2.0. Bioinformatics 2007; 23:2947-2948

Lévine A, Vannier F, Absalon C, Kuhn J, Jackson P, Scrivener E, Labas V, Vinh J, Courtney P, Garin J, Séror S: Analysis of the dynamic $\mathrm{Ba}$ cillus subtilis Ser/Thr/Tyr phosphoproteome implicated in a wide variety of cellular processes. Proteomics 2006;6:2157-2173.

Lomas-Lopez R, Paracuellos P, Riberty M, Cozzone AJ, Duclos B: Several enzymes of the central metabolism are phosphorylated in Staphylococcus aureus. FEMS Microbiol Lett 2007;272:35-42.

Macek B, Gnad F, Soufi B, Kumar C, Olsen JV, Mijakovic I, Mann M: Phosphoproteome analysis of $E$. coli reveals evolutionary conservation of bacterial Ser/Thr/Tyr phosphorylation. Mol Cell Proteomics 2008;7:299307.

Macek B, Mijakovic I, Olsen JV, Gnad F, Kumar C, Jensen PR, Mann M: The serine/threonine/tyrosine phosphoproteome of the model bacterium Bacillus subtilis. Mol Cell Proteomics 2007;6:697-707.

-Madec E, Laszkiewicz A, Iwanicki A, Obuchowski M, Séror S: Characterization of a membrane-linked Ser/Thr protein kinase in Bacillus subtilis, implicated in developmental processes. Mol Microbiol 2002;46:571586.
Madec E, Stensballe A, Kjellström S, Cladière L, Obuchowski M, Jensen ON, Séror S: Mass spectrometry and site-directed mutagenesis identify several autophosphorylated residues required for the activity of PrkC, a Ser/Thr kinase from Bacillus subtilis. J Mol Biol 2003; 330:459-472.

-Martin-Verstraete I, Stülke J, Klier A, Rapoport G: Two different mechanisms mediate catabolite repression of the Bacillus subtilis levanase operon. J Bacteriol 1995;177:6919-6927.

-Merzbacher M, Detsch C, Hillen W, Stülke J: Mycoplasma pneumoniae HPr kinase/phosphorylase: assigning functional roles to the P-loop and the HPrK/P signature sequence motif. Eur J Biochem 2004;271:367-374.

-Mijakovic I, Poncet S, Galiner A, Monedero V, Fieulaine S, Janin J, Nessler S, Marquez JA, Scheffzek K, Hasenbein S, Hengstenberg W, Deutscher J: Pyrophosphate-producing protein dephosphorylation by HPr kinase/phosphorylase: a relic of early life? Proc Natl Acad Sci USA 2002;99:13442-13447.

- Min KT, Hilditch CM, Diederich B, Errington J, Yudkin MD: Sigma F, the first compartment-specific transcription factor of $B$. subtilis, is regulated by an anti-sigma factor that is also a protein kinase. Cell 1993;27:735742 .

-Moreno MS, Schneider BL, Maile RR, Weyler W, Saier MH Jr: Catabolite repression mediated by the CcpA protein in Bacillus subtilis: novel modes of regulation revealed by whole-genome analysis. Mol Microbiol 2001;39:13661381.

- Nováková L, Sasková L, Pallová P, Janecek J, Novotná J, Ulrych A, Echenique J, Trombe MC, Branny P: Characterization of a eukaryotic type serine/threonine protein kinase and protein phosphatase of Streptococcus pneumoniae and identification of kinase substrates. FEBS J 2005;272:1243-1254.

-Reizer J, Bachem S, Reizer A, Arnaud M, Saier MH Jr, Stülke J: Novel phosphotransferase system genes revealed by genome analysis the complete complement of PTS proteins encoded within the genome of Bacillus subtilis. Microbiology 1999;145:3419-3429.

Reizer J, Hoischen C, Titgemeyer F, Rivolta C, Rabus R, Stülke J, Karamata D, Saier MH Jr, Hillen W: A novel bacterial protein kinase that controls carbon catabolite repression. Mol Microbiol 1998;27:1157-1169.

Sambrook J, Fritsch EF, Maniatis T: Molecular Cloning: A Laboratory Manual, ed 2. Cold Spring Harbor Laboratory, Cold Spring Harbor, 1989 .

- Sasková L, Nováková L, Basler M, Branny P: Eukaryotic-type serine/threonine protein kinase $\mathrm{StkP}$ is a global regulator of gene expression in Streptococcus pneumoniae. J Bacteriol 2007;189:4168-4179. 
- Schilling O, Frick O, Herzberg C, Ehrenreich A, Heinzle E, Wittmann C, Stülke J: Transcriptional and metabolic responses of Bacillus subtilis to the availability of organic acids: transcription regulation is important but not sufficient to account for metabolic adaptation. Appl Env Microbiol 2007;73:499-507.

-Schirmer F, Ehrt S, Hillen W: Expression, inducer spectrum domain structure, and function of MopR, the regulator of phenol degradation in Acinetobacter calcoaceticus NCIB8250. J Bacteriol 1997;179:1329-1336.

Schmalisch MH, Bachem S, Stülke J: Control of the Bacillus subtilis antiterminator protein GlcT by phosphorylation: elucidation of the phosphorylation chain leading to inactivation of GlcT. J Biol Chem 2003;278:5110851115.
-Schmidl SR, Gronau K, Hames C, Busse J, Becher D, Hecker M, Stülke J: The stability of cytadherence proteins in Mycoplasma pneumoniae requires activity of the protein kinase PrkC. Infect Immun 2010;78:184-192.

Shah IM, Laaberki MH, Popham DL, Dworkin J: A eukaryotic-like Ser/Thr kinase signals bacteria to exit dormancy in response to peptidoglycan fragments. Cell 2008; 135 :486496.

Shakir SM, Bryant KM, Larabee JL, Hamm EE, Lovchik J, Lyons CR, Ballard JD: Regulatory interactions of a virulence-associated serine/ threonine phosphatase-kinase pair in Bacillus anthracis. J Bacteriol 2010;192:400-409.

Singh KD, Halbedel S, Görke B, Stülke J: Control of the phosphorylation state of the HPr protein of the phosphotransferase system in $\mathrm{Ba}$ cillus subtilis: implication of the protein phosphatase PrpC. J Mol Microbiol Biotechnol 2007;13:165-171.
Su HC, Hutchison CA, Giddings MC: Mapping phosphoproteins in Mycoplasma genitalium and Mycoplasma pneumoniae. BMC Microbiol 2007;7:63.

- Tjalsma H, Antelmann H, Jongbloed JDH, Braun PG, Darmon E, Dorenbos R, Dubois JYF, Westers H, Zanen G, Quax WJ, Kuipers OP, Bron S, Hecker M, van Dijl JM: Proteomics of protein secretion by Bacillus subtilis: separating the 'secrets' of the secretome. Microbiol Mol Biol Rev 2004;68:207-233.

Yang X, Kang CM, Brody MS, Price CW: Opposing pairs of serine protein kinases and phosphatases transmit signals of environmental stress to activate a bacterial transcription factor. Genes Dev 1996;10:2265-2275. 